\title{
Gas turbines: Gas Cleaning Requirements for Biomass-Fired Systems
}

\author{
John Oakey*, Nigel Simms, Paul Kilgallon \\ Power Generation Technology Centre, Cranfield University, Bedford, UK
}

Received: September 2, 2002; Revised: September 4, 2002

\begin{abstract}
Increased interest in the development of renewable energy technologies has been hencouraged by the introduction of legislative measures in Europe to reduce $\mathrm{CO}_{2}$ emissions from power generation in response to the potential threat of global warming. Of these technologies, biomass-firing represents a high priority because of the modest risk involved and the availability of waste biomass in many countries. Options based on farmed biomass are also under development.

This paper reviews the challenges facing these technologies if they are to be cost competitive while delivering the supposed environmental benefits. In particular, it focuses on the use of biomass in gasification-based systems using gas turbines to deliver increased efficiencies. Results from recent studies in a European programme are presented. For these technologies to be successful, an optimal balance has to be achieved between the high cost of cleaning fuel gases, the reliability of the gas turbine and the fuel flexibility of the overall system. Such optimisation is necessary on a case-bycase basis, as local considerations can play a significant part.
\end{abstract}

Keywords: biomass, gas turbines, gas cleaning

\section{Introduction}

Increased interest in the development of renewable energy technologies has been encouraged by introduction of legislative measures in Europe to reduce $\mathrm{CO}_{2}$ emissions from power generation in response to the potential threat of global warming. Of these technologies, biomass-firing represents a high priority because of the modest technological risk involved and the availability of waste biomass in many countries ${ }^{1}$. Options based on farmed biomass are also under development.

While combustion of waste and farmed biomass has been practised for many years around the world, system efficiencies have always fallen well below those of equivalent fossil-fired systems. In most cases this has been due to the reduced steam conditions enforced by the severe fouling and corrosion problems experienced as a result of the high contaminant levels (e.g. $\mathrm{Na}, \mathrm{K}, \mathrm{Cl}, \mathrm{Pb}$, etc) with many biomass fuels which also lead to reduced component lives. While coal plants are targeting $650{ }^{\circ} \mathrm{C} / 300$ bar steam and above, biomass plants are currently operating at less than $540{ }^{\circ} \mathrm{C} / 100$ bar steam with efficiencies of typically less than $30 \%$.

In Denmark, where government legislation has driven the introduction of ever more efficient plants, the most advanced straw-fired biomass plant operate at $540{ }^{\circ} \mathrm{C} / 92$ bar with an electrical efficiency of $29 \%$. Experience from boilers in Sweden firing 100\% forest fuel, indicates that conventional superheater steels last no longer than four years or 20,000 h before they must be replaced because of corrosion damage. Overall, this leads to higher operating costs making biomass combustion plants uncompetitive compared to fossil plants, unless supported in some way through subsidies or grants. Moving towards cheaper waste biomass sources (such as demolition wood) to improve the overall plant economics, has been found to lead to even more severe problems. In addition to the impact of biomass fuels on operating costs, the capital costs of biomass plants are usually higher than their fossil counterparts due to more complex fuel feeding arrangements, fuel drying, gas cleaning, emissions monitoring requirements, etc.

In order to improve system efficiencies and improve the economics of biomass plants, recent interest has focused on gasification combined cycle systems which use turbines and advanced gas engines. While different gasification options are possible ${ }^{2}$, circulating fluidised bed gasifiers 
have been developed to the greatest extent due to their flexibility and suitability for the scale of available biomass feedstocks. Both atmospheric pressure and pressurised schemes have been demonstrated at a scale using a small industrial gas turbine (e.g. an ALSTOM Power $\sim 4 \mathrm{MW}_{\mathrm{e}}$ Typhoon).

Based on the TPS Termiska Processer AB circulating bed gasification system ${ }^{3}$ from Sweden, the world's first 'commercial' biomass gasification plant (known as the ARBRE project) is undergoing commissioning at Eggborough, Yorkshire in the UK. This plant uses coppiced willow and forestry residues in chipped form and produces $8 \mathrm{MW}$ of electricity with a cycle efficiency of $\sim 31 \%$. A generic flowsheet for the hot gas path of this plant through to the gas turbine is shown in Fig. 1.

This figure shows the complexity of the hot gas path in such systems. Even though fluidised bed gasifiers lead to moderate fuel gas tar levels, a high temperature cracker is used to reduce energy losses and to limit the tar removal burden at the gas purification/scrubbing stage. Tars would otherwise cause problems in the gas compressor. Ammonia levels in the fuel gas are a further concern as they will lead to excessive $\mathrm{NO}_{\mathrm{x}}$ levels in the gas turbine exhaust and exceed the allowable emissions limits.

In a pressurised system, such as the that in the Varnamo project $^{4}$ operated by Sydkraft AB using Foster Wheeler gasifier technology from Finland, there is no requirement for a fuel gas compressor (see Figure 2). So, tars can be kept hot (in the vapour phase) provided they do not exceed the gas turbine entry limits and do not cause blinding problems in the hot gas filter. Being at high pressure and using a hot gas cleaning approach reduces the complexity of the hot gas path and raises the cycle efficiency. The measured efficiency in the Varnamo project was $32 \%$ but up to $38 \%$ could be expected from application of the latest gas and

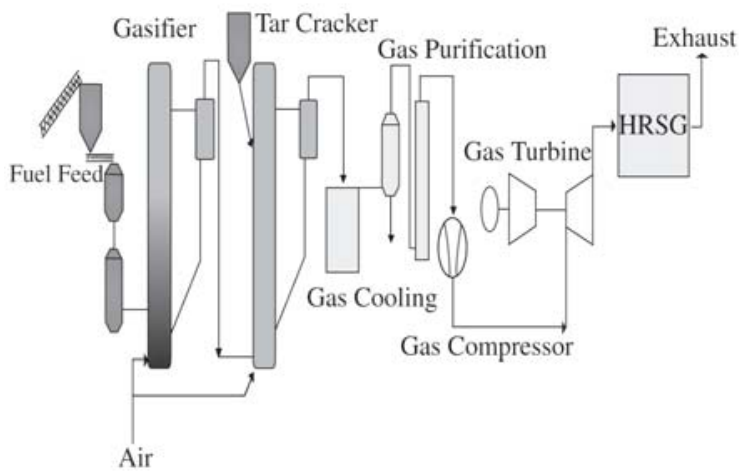

Figure 1. Simplified flowsheet for the hot gas path of the ARBRE project. steam turbine technology. This scheme used a variety of biomass fuels to demonstrate its flexibility and produced $5 \mathrm{MW}$ of electricity and $9 \mathrm{MW}$ of heat for district heating. Figure 2 shows the hot gas path through to the gas turbine.

So, while the gasification approach leads to higher efficiencies, it is more complex and expensive to build. It is also susceptible to problems associated with the same contaminants which have led to the operational restrictions experienced with biomass combustion plant. The remainder of this paper reviews the possible effects of contaminants in biomass gasification systems as described above, with particular reference to the durability of the gas turbine and the implications this may have for gas cleaning requirements.

\section{Biomass Characteristics and Effects on Fuel Gas Contaminants}

Like coal, biomass contains a wide range of elements that may react to form potentially harmful deposits in gasification systems and their gas turbines. The 'mix' of elements in the fuel gases produced in a gasification process will be highly dependent on the biomass fuel composition. Before biomass-firing can be used with any confidence in gasification systems, it is necessary to investigate the effects the deposits and gas environments will have on the gas turbine components in such systems. From such information, fuel specifications for biomass-fired gas turbines can be derived, to ensure adequate lives for components and to permit the use of state-of-the-art gas turbines.

In order to investigate the contaminant effects in the hot gas path of biomass gasification plants, it is necessary to understand the levels in biomass fuels relative to those in coals for which there is wide experience in combined cycle gasification systems. Extensive composition infor-

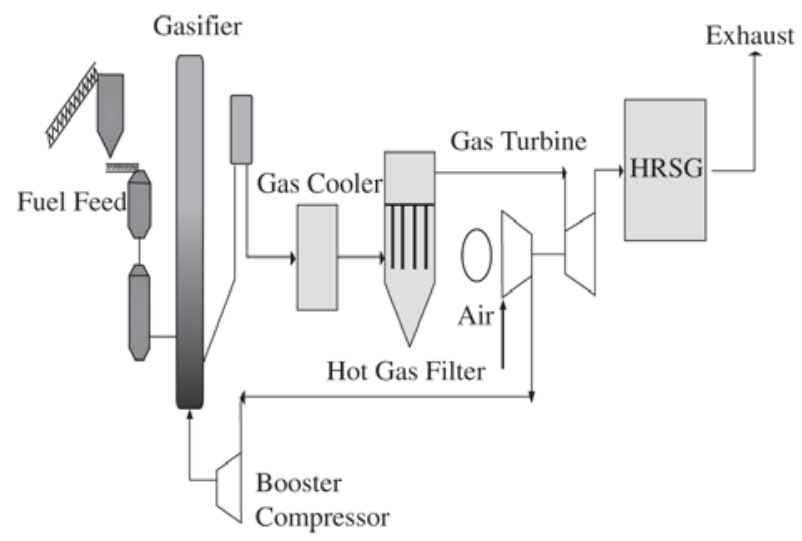

Figure 2. Flowsheet for the hot gas path of the Varnamo project. 
mation has been gathered on potential European biomass fuels ${ }^{5}$; but few of these analyses have been carried out for all minor and trace metal species. Average data values for pine wood, wheat straw, a range of grasses, sewage sludge and peat, with coal for comparison are given in Tables 1 and 2; but it should be noted that there are significant differences in the errors associated with each of these values due to inherent fuel variations, the varying numbers of references used to determine each value and the various analytical methods used.

Table 1 illustrates the major differences between biomass fuels and coal. In general terms, they have higher moisture, lower ash (except sewage sludge), lower S and similar or higher $\mathrm{Cl}$. Table 2 presents average ash compositions derived using standard ash analysis techniques derived to give comparable data for combustion systems. Noting the differences in ash contents from Table 1, it is also generally true that biomass fuels contain higher levels of alkali metals, in particular K. While, it must be noted that the artificial method used to generate ash for analysis was designed for coal combustion, the general findings listed do suggest that fouling and corrosion problems should be expected in biomass systems. Overall, there is a tendency for the higher $\mathrm{Cl} /$ lower $\mathrm{S}$ levels to favour the formation of chlorides over sulphates while the lower ash contents provide less dilution of any deposits formed on plant components.

It is thought that the high $\mathrm{K}$ content combined with $\mathrm{Cl}$ is also responsible for the formation of low melting temperature compounds during combustion; the low S content

Table 1. Average analyses of biomass and fossil fuels.

\begin{tabular}{lccccc}
\hline & Wood & $\begin{array}{c}\text { Wheat 'Grass' } \\
\text { Straw }\end{array}$ & $\begin{array}{l}\text { Sewage } \\
\text { Sludge }\end{array}$ & Coal \\
\hline Moisture (wt\%) & 20.7 & 10.7 & 14.9 & 19.5 & 8.2 \\
Ash (wt\%) & 1.7 & 5.9 & 5.2 & 43.4 & 12.7 \\
S (wt\%) & 0.2 & 0.1 & 0.2 & 1.0 & 1.7 \\
Cl (wt\%) & 0.1 & 0.8 & 0.2 & 0.1 & 0.2 \\
LHV, MJ/kg & 18.6 & 17.3 & 18.3 & 10.7 & 26.2 \\
\hline
\end{tabular}

in many biomass fuels is another contributing factor. These low melting point ash constituents have led to the widespread fouling and severe corrosion problems experienced.

In gasification systems, the situation is somewhat different. There are several possible routes for minor and trace elements, such as $\mathrm{Na}$ or $\mathrm{K}$, to take within a gasification system and through into the gas turbine. These routes vary from no response to the gasification process (and so exit with the ash/char/slag) through to the formation of vapour species that can pass through the whole hot gas path (and so be emitted from the process). In between these two extremes, it is possible for reactions to take place forming (a) condensed particles and (b) vapour species that can condense onto entrained particles or plant components (depending on their specific operating conditions) along the hot gas path. The fate of the various trace elements is element-specific and in addition can be influenced by both the relative and absolute levels of other elements present in the fuels (e.g. $\mathrm{S}$ and $\mathrm{Cl}$ ) and in any sorbents or catalysts used, as well as the composition of materials used for hot gas path components.

In order to determine the potential fate of trace elements within gasification systems using biomass fuels, one approach is to investigate the thermodynamic equilibrium at various process stages. The thermodynamic analysis package, MTDATA, has been used to predict trace element behaviour followed by comparison of the trends identified with reported plant data and known operating experience. One of the aims of this work was to enable studies to be more closely focused on realistic deposit compositions when carrying out corrosion testing on materials intended for use within gasifier and gas turbine hot gas paths.

The thermodynamic study was carried out to determine which trace elements were more/less likely to enter the hot gas paths of gasification systems, condense onto system components and/or pass through into the gas turbine. This study investigated the stability of potential product compounds in gasifier fuel gases and their sensitivity to a number of important process variables:

- two example gasifier processes: an oxygen blown entrained flow process and an air blown fluidised bed process $^{2,6}$

Table 2. Ash analyses of biomass and fossil fuels.

\begin{tabular}{lcccccccccc}
\hline & $\mathrm{Al}_{2} \mathrm{O}_{3}$ & $\mathrm{SiO}_{2}$ & $\mathrm{Na}_{2} \mathrm{O}$ & $\mathrm{K}_{2} \mathrm{O}$ & $\mathrm{MgO}$ & $\mathrm{CaO}$ & $\mathrm{Fe}_{2} \mathrm{O}_{3}$ & $\mathrm{P}_{2} \mathrm{O}_{5}$ & $\mathrm{SO}_{3}$ & $\mathrm{TiO}_{2}$ \\
\hline Wood & 5.5 & 24.3 & 1.7 & 9.3 & 4.5 & 34.5 & 3.6 & 5.6 & 5.5 & 0.4 \\
Wheat Straw & 1.8 & 49.6 & 3.7 & 22.2 & 2.9 & 6.0 & 1.0 & 2.6 & 3.3 & 0.1 \\
Grass & 2.8 & 59.5 & 0.7 & 15.3 & 3.4 & 7.4 & 1.6 & 8.6 & 1.4 & 0.2 \\
Sewage Sludge & 15.0 & 34.6 & 1.0 & 1.4 & 3.1 & 17.3 & 10.6 & 10.0 & 1.3 & 1.0 \\
Coal & 18.1 & 40.8 & 3.5 & 2.4 & 3.8 & 10.3 & 12.3 & 6.2 & 6.2 & 0.8 \\
\hline
\end{tabular}


- atmospheric and pressurised operation

- temperature ranges covering gasification and hot gas cleaning processes, as well as component operating temperatures

- a range of $\mathrm{S}$ and $\mathrm{Cl}$ levels to cover the potential ranges of fuels in coal and coal/biomass fired systems

- the elements As, B, Ba, Be, Ca, Cd, Co, Cu, Hg, K, Mn, $\mathrm{Mo}, \mathrm{Na}, \mathrm{Pb}, \mathrm{Sb}, \mathrm{Se}, \mathrm{Sn}, \mathrm{V}, \mathrm{Zn}$ (Cr, Ni and Fe were not investigated as they are major alloying elements in materials used in components throughout the fuel gas paths).

Published literature surveys ${ }^{7-10}$ were critically evaluated and care taken to avoid the pitfalls identified. For a power plant, it is important to note that kinetic effects may arise due to short gas residence times and/or slow reaction rates that could limit movement towards thermodynamic equilibrium. These effects apply especially to the bulk gases and will be less significant in the slower moving boundary layers adjacent to components.

The results of this thermodynamic study are reported elsewhere ${ }^{11}$. Table 3 lists the major gaseous and condensed phases and the temperature ranges for transitions between the gaseous and condensed states in gasification conditions. It should be noted that even elements with condensed phases can have significant vapour pressures. Table 4 groups the elements in terms of their 'volatility', i.e. in order of the transitions from gaseous to condensed phases. This table does not correspond with the frequently quoted three-group classification of trace elements ${ }^{10}$. This classification was originally developed for combustion systems and some reports directly translate this to gasification systems. As sometimes noted before ${ }^{7,9}$ and found in this study, the same classification of elements is not applicable to combustion and gasification systems (and indeed there are several significant differences between types of gasification system).

Figure 3 provides an example of the data generated during the thermochemical modelling; it shows the effect

Table 4. Predicted volatility of trace and alkali metals in gasification gases.

\begin{tabular}{cl}
\hline Increasing Volatility & Element \\
\hline & $\mathrm{Hg}, \mathrm{Sb}, \mathrm{Se}(\mathrm{As}, \mathrm{V}, \mathrm{B})$ \\
$\mathrm{Cd}, \mathrm{Pb}, \mathrm{Sn}, \mathrm{Zn}(\mathrm{As}, \mathrm{B})$ & $\mathrm{Co}, \mathrm{Cu}, \mathrm{K}, \mathrm{Mn}, \mathrm{Mo}, \mathrm{Na}$ \\
& $\mathrm{As}, \mathrm{Ba}, \mathrm{Be}$ \\
& $\mathrm{Ca}(\mathrm{V}, \mathrm{As}, \mathrm{B})$ \\
\hline
\end{tabular}

Note: ()$=$ significant differences in behaviour predicted for different gas conditions

Table 3. Summary of trace and alkali metal behaviour in gasifier gases.

\begin{tabular}{|c|c|c|c|}
\hline Element & Major Gas Species & Major Solid Species & $\begin{array}{l}\text { Gas } \rightarrow \text { Solid Transformation } \\
\text { Temperature Range }\left({ }^{\circ} \mathrm{C}\right)\end{array}$ \\
\hline As & $\mathrm{As}, \mathrm{As}_{2}, \mathrm{As}_{4}, \mathrm{AsS}$ & - & - \\
\hline As $(+\mathrm{Ni})$ & AsS (As) & $\mathrm{As}_{2} \mathrm{Ni}_{5}, \mathrm{As}_{8} \mathrm{Ni}_{11}$ & $1020-1460$ \\
\hline $\mathrm{B}$ & $\mathrm{BHO}_{2}, \mathrm{~B}(\mathrm{OH})_{3}$ & - & - \\
\hline $\mathrm{B}(+\mathrm{Ca})$ & $\mathrm{B}(\mathrm{OH})_{3}\left(\mathrm{BHO}_{2}\right)$ & $\mathrm{B}_{2} \mathrm{Ca}_{3} \mathrm{O}_{6}$ & Solid®gas 420-840 \\
\hline $\mathrm{Ba}$ & $\mathrm{BaCl}_{2}, \mathrm{BaClHO}$ & $\mathrm{BaCl}_{2}, \mathrm{BaS} \mathrm{BaCO}_{3}$ & $900-1040($ or $>1200)$ \\
\hline $\mathrm{Be}$ & $\mathrm{BeH}_{2} \mathrm{O}_{2}$ & $\mathrm{BeO}$ & $840-960$ \\
\hline $\mathrm{Ca}$ & $\mathrm{CaCl}_{2}, \mathrm{CaS}, \mathrm{CaCO}_{3}$ & - & - \\
\hline $\mathrm{Cd}$ & $\mathrm{Cd}, \mathrm{CdCl}_{2}$ & $\mathrm{CdS}$ & $400-540($ or $<400)$ \\
\hline $\mathrm{Co}$ & $\mathrm{CoCl}_{2}(\mathrm{Co})$ & $\mathrm{Co}, \mathrm{Co}_{9} \mathrm{~S}_{8}$ & $600-1340$ \\
\hline $\mathrm{Cu}$ & $\mathrm{CuCl}, \mathrm{Cu}_{3} \mathrm{Cl}_{3}(\mathrm{Cu}, \mathrm{CuH})$ & $\mathrm{Cu}, \mathrm{Cu}_{2} \mathrm{~S}$ & $520-960$ \\
\hline $\mathrm{Hg}$ & $\mathrm{Hg}$ & - & - \\
\hline $\mathrm{K}$ & $\mathrm{KCl}, \mathrm{K}_{2} \mathrm{Cl}_{2}$ & $\mathrm{KCl}$ & $700-900$ \\
\hline $\mathrm{Mn}$ & $\mathrm{MnCl}_{2}(\mathrm{MnCl})$ & $\mathrm{MnO}, \mathrm{MnS}$ & $440-1260$ \\
\hline Mo & $\mathrm{MoClO}_{2}, \mathrm{MoCl}_{2} \mathrm{O}, \mathrm{MoCl}_{2} \mathrm{O}_{2}\left(\mathrm{MoHO}_{2}\right)$ & $\mathrm{MoS}_{2}$ & $700-1200$ \\
\hline $\mathrm{Na}$ & $\mathrm{NaCl}, \mathrm{Na}_{2} \mathrm{Cl}_{2}$ & $\mathrm{NaCl}$ & $670-900$ \\
\hline $\mathrm{Pb}$ & $\mathrm{Pb}, \mathrm{PbCl}, \mathrm{PbCl}_{2} \mathrm{PbS}$ & $\mathrm{Pb}, \mathrm{PbS}$ & $560-640($ or $<400)$ \\
\hline $\mathrm{Sb}$ & $\mathrm{SbCl}(\mathrm{Sb})$ & - & - \\
\hline $\mathrm{Se}$ & $\mathrm{SeH}_{2}(\mathrm{SeH})$ & - & - \\
\hline $\mathrm{Sn}$ & $\mathrm{SnS}, \mathrm{SnCl}_{2}$ & $\mathrm{SnO}_{2}, \mathrm{SnS}$ & $460-560($ or $<400)$ \\
\hline V & $\left(\mathrm{VCl}_{2}, \mathrm{VCl}_{3}, \mathrm{VOCl}_{3}\right)$ & $\mathrm{V}_{2} \mathrm{O}_{3}$ & - \\
\hline $\mathrm{Zn}$ & $\mathrm{Zn}, \mathrm{ZnCl}_{2}$ & $\mathrm{ZnS}$ & $460-780$ \\
\hline
\end{tabular}


of increasing the pressure on the K equilibrium diagram for an air-generated fuel gas. The gas to solid transformation temperature of the major species, $\mathrm{KCl}$, is increased from $\sim 700{ }^{\circ} \mathrm{C}$ to $\sim 900{ }^{\circ} \mathrm{C}$ when the pressure increases from 1 to $20 \mathrm{~atm}$. Thus, subject to kinetic effects, increasing pressure can be expected to lead to condensation of $\mathrm{KCl}$ on higher temperature surfaces in the gasifier hot gas path, reducing the remaining levels of $\mathrm{K}$ vapour species in the fuel gas.

Other gas species can also influence condensation (dewpoint) temperatures. For example, increased levels of $\mathrm{H}_{2} \mathrm{~S}$ can give, for different elements, higher or lower dewpoints (e.g. Zn or Sn) or different gas phase and/or condensed species (e.g. Pb), so care is needed to ensure that the fuel gas compositions being modelled are complete and realistic.

To substantiate the effects identified by thermodynamic modelling, relevant process data were sought. There are some data for the removal of alkali, trace metals and chlorine species in gasification systems incorporating hot gas filters ${ }^{7,12-17}$. These data are not comprehensive and as each gasification system has used different filtering temperatures, it is difficult to separate process differences from differences arising from the use of different filter temperatures. However, it is reasonable to assume that reducing filter operating temperatures will reduce the passage of vapour phase contaminants through to the gas turbine, as it will drive the equilibrium towards condensed phases and reduce the vapour pressure of the species remaining in the gas.

In many cases (e.g. for alkali metals, Zn, etc.), the pre- ferred route of removal on economic grounds is by condensation/reaction with the fine particles present in the gas stream followed by particle removal by the hot gas filter. However, the coldest component in this hot gas path will be the heat exchanger that cools the gases prior to entry into the filter. The presence of 'trace' metals in heat exchanger deposits at levels of several wt $\%$ has been frequently observed during component examinations and assessments (but only occasionally reported ${ }^{18,19}$ ). The large internal surfaces of the heat exchanger, ductwork and the filter unit itself provide potential sinks for condensed alkali/trace metals, especially if they are cooler than the gas stream. In a pressurised air blown fluidised bed gasifier pilot plant ${ }^{7}$, deposits of the more volatile 'trace' metals at levels of several $\mathrm{wt} \%$ were observed on the surfaces of pipes on the 'clean' side of the filter unit. In addition, a reduction in S and $\mathrm{Cl}$-containing species has been noted across hot gas filter units, presumably as a result of reactions with the filter cake formed on the dirty side of the filter units.

The information available for alkali and trace metal species all show that lowering the filter temperature reduces the amount of vapour phase species present in the remaining fuel gas stream (and enriches the filter fines in these elements) ${ }^{7,20}$. Unfortunately, filter operating temperatures cannot just be lowered to the levels needed to remove most of these vapour species, as the lower limits for filter operation are dictated by other gasification processes parameters: e.g. tars and ammonia-derived compounds need to be kept in the vapour phase to avoid blinding of the filters. The
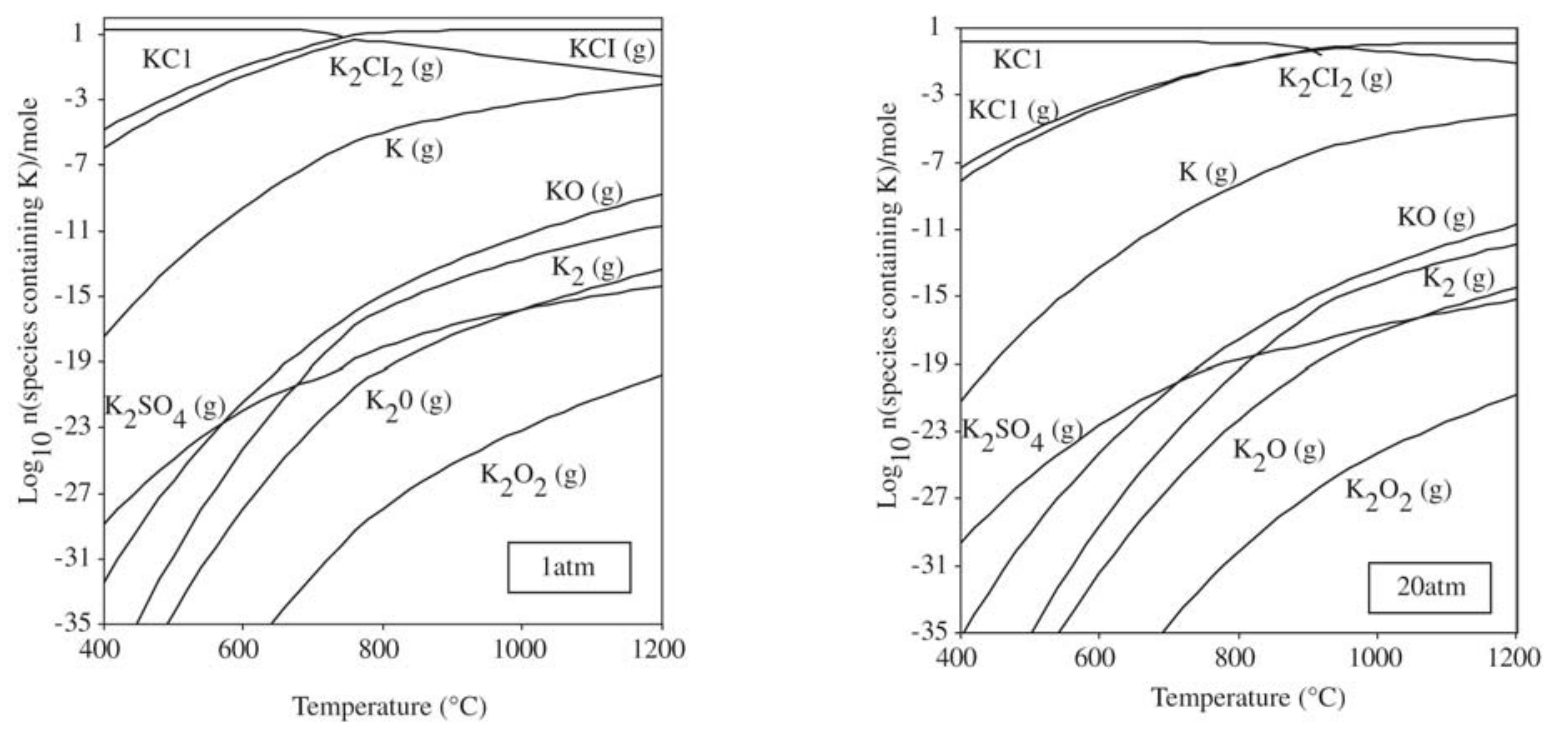

Figure 3 The effect of pressure on K equilibrium diagrams in air-derived fuel gases. 
available data are most comprehensive for alkali species on which many studies have been targeted. This is despite the importance of other trace elements, e.g. $\mathrm{Pb}$, which are present at similar, if not higher, levels in gasification fuel gas streams and are also important in determining gas turbine component lives ${ }^{7,14-16}$. In work carried out at $\mathrm{VTT}^{13}$, the most significant levels of elements found in the fuel gas were for $\mathrm{Cd}, \mathrm{Pb}$ and $\mathrm{Zn}$. The levels of several trace metals (e.g. $\mathrm{Pb}$ ) and alkalis (e.g. $\mathrm{Na}, \mathrm{K}$ ) reported in these studies are higher than those currently acceptable for gas turbines, and in some cases it is likely that the true values of vapour phases species in the gasifier product gases are higher still?

From plant data, filter temperatures below $400^{\circ} \mathrm{C}$ may be required to reduce contaminants to acceptable levels for the gas turbine. In other cases, supplementary gas cleaning stages or the use of a scrubber may be required or the use of a scrubber to meet the required target, impacting significantly on costs and cycle efficiency. But the level acceptable to the turbine depends on the life required of gas turbine parts, the temperatures at which they work and the materials/coatings used, so there is potential scope for compromise here also. This is discussed later in this paper.

The main points arising from the above analysis are summarised as follows: (i) fuel composition: on a mass comparison basis, the critical contaminants species ( $\mathrm{S}, \mathrm{Cl}$, alkalis and trace metals) of many biomasses are similar or lower than coal - notable exceptions are $\mathrm{K}$ and $\mathrm{Cl}$ in straw; $\mathrm{P}, \mathrm{Cd}$, $\mathrm{Pb}$ and $\mathrm{Zn}$ in wood (as well as $\mathrm{Ba}, \mathrm{Cr}, \mathrm{Cu}, \mathrm{Mn}$ ); $\mathrm{V}$ and $\mathrm{Zn}$ in sewage sludge (as well as $\mathrm{Cr}, \mathrm{Cu}, \mathrm{Mn}, \mathrm{Hg}$ ); (ii) fuel gas compositions vary significantly between gasification systems at the trace contaminant level (as well as the frequently reported bulk gas composition level); (iii) most trace and alkali metals are more volatile in gasification systems than in combustion systems - the same classification of volatility as for combustion gases is not applicable (different species are volatile); (iv) Sand $\mathrm{Cl}$ levels (both absolute and relative), as well as operating pressure and gasification process can influence the volatility of trace and alkali metal species; (v) potentially damaging levels of $\mathrm{Pb}, \mathrm{Zn}, \mathrm{Cd}$ and $\mathrm{Sn}$ (and V in some systems) can all pass through the fuel gas path to the gas turbine, as well as alkali metals $(\mathrm{Hg}, \mathrm{B}, \mathrm{Sb}$ and Se can also pass through the gas turbine); and, (vi) the high levels of trace metals present in gasifier product gases can be reduced by use of low filter operating temperatures (e.g. $250-450{ }^{\circ} \mathrm{C}$ dependent on the gasification system).

\section{Contaminant Effects on Gas Turbine Components}

In all biomass combined cycle systems the performance of the gas turbine is vital to the overall plant efficiency and economic viability. However, within these systems hot corrosion and/or erosion are likely to be life limiting for the gas turbine vanes and blades, rather than the creep and fatigue processes that limit their lives in the longer term due to the expected contaminant levels.

The environments found within the hot gas paths of gas turbines depend on the contaminants present in the fuel and air entering the turbine, as well as the turbine operating conditions. Industrial gas turbines have been developed to fire on a wide variety of fuels, ranging from natural gas to sour gases and heavy fuel oils. The degradation of materials in such systems has been the subject of many investigations during the past 40 years, as operating conditions have developed and/or fuels have changed, and the potential problems which many be encountered in gas and oil fired gas turbines have been well characterised ${ }^{21,22}$.

Many similar types of materials degradation can be expected in gas turbines using solid fuel derived fuel gases, as some of the contaminant species are the same as for oil and/or gas fired systems. However, the contaminant levels are different, there are additional as well as absent species and the sources/forms of the contaminant species also differ. Fuel gases derived from biomass have the potential to cause both erosion and corrosion damage to gas turbine hot gas path components. Fuel derived particles can cause either erosion damage or deposition depending on the particles' size and composition, as well as aerofoil design and operating conditions. Corrosion can result from the combined effects of gaseous species (e.g. $\mathrm{SO}_{x}$ and $\mathrm{HCl}$ ) and deposits formed by condensation from the vapour phase (e.g. alkalis and other trace metal species) and/or particle impaction and sticking.

The mode of corrosion damage is highly dependent on the local component environment. Conventionally, the metal vapour species of most concern were alkalis (mainly $\mathrm{Na}$ ) and $\mathrm{S}$ in gas turbines fired on clean fuels (either as fuel contaminants or via the combustion air) or $\mathrm{V}$ from heavy fuel oils. In biomass fired systems the levels of both $\mathrm{SO}_{\mathrm{X}}$ and $\mathrm{HCl}$ can be similar to (or higher for HCL) than those from a coal gasifier (see Table 1). Also, the fuel gas may contain significant levels of alkali metals (in particular $\mathrm{K}$ ) and heavy metals, e.g. $\mathrm{Pb}$ and $\mathrm{Zn}^{23}$, depending on the type of biomass (Table 2) and the effectiveness of the gas cleaning approach. If a water or chemical scrubber is included (as in the ARBRE scheme for ammonia removal), the levels of these contaminants will be significantly reduced whereas a hot dry cleaning approach will potentially lead to higher levels, depending on the operating temperature of the filter.

The effects of different fuels on the levels of contaminant vapour phase species, deposition fluxes and deposit compositions (e.g. melting points) requires careful consideration for each process and fuel. Thus, fuel and air quality standards produced for gas turbines fired on more traditional fuels [e.g. 24] need to be thoroughly reviewed and 
revised $^{25-26}$, to take into account the significant differences with these new fuel compositions, as well as the damage rates that will be acceptable for these new power systems.

In order to identify whether the residual levels of contaminants (such as K) in a 'cleaned', biomass-derived fuel gas will restrict the operating life of gas turbine components, it is necessary to understand their deposition behaviour and the effects the resultant deposit may have on the blade and vane materials and coatings.

Thermodynamic analysis methods were also applied to the gas turbine, using the results of the gasifier fuel gas study to identify the elements that can pass through into the gas turbine, as well as realistic ranges for the different contaminant levels. Figure 4 illustrates the results obtained for $\mathrm{K}$ dewpoint temperatures, which are plotted as a function of contaminant levels for different $\mathrm{SO}_{\mathrm{X}}$ and $\mathrm{HCl}$ levels and gas pressures. In a gas turbine combustion gas, $\mathrm{K}_{2} \mathrm{SO}_{4}$ is the equilibrium $\mathrm{K}$ compound in deposits rather than $\mathrm{KCl}$ which will persist in the gas phase. Figure 4 shows that the $\mathrm{K}_{2} \mathrm{SO}_{4}$ dewpoint increases with increasing $\mathrm{K}$ or $\mathrm{SO}_{\mathrm{X}}$ levels in the gas stream, as well as gas pressure, but decreases with increasing $\mathrm{HCl}$ levels in the gas stream.

Once deposited, there are significant differences between the effects of the various deposits; described in detail elsewhere ${ }^{27,28}$. This is illustrated in Fig. 5 for a 'deposition flux' of $5 \mu \mathrm{g} / \mathrm{cm}^{2} / \mathrm{h}$, in which 'maximum' corrosion damage values ( damage with a $4 \%$ probability of being exceeded) are plotted as a function of exposure time(data from laboratory

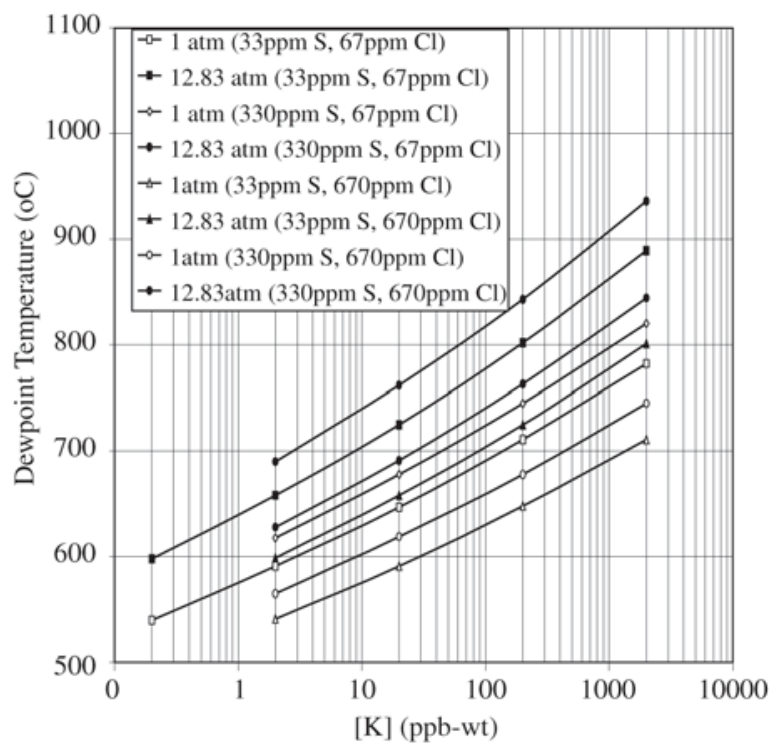

Figure 4. Dependence of $\mathrm{K}_{2} \mathrm{SO}_{4}$ dewpoint on gas pressure, $\mathrm{S}, \mathrm{Cl}$ and $\mathrm{K}$ levels corrosion tests). The samples with this 'deposition flux' at $700{ }^{\circ} \mathrm{C}$ have a clear incubation period for all the various deposit compositions. However, this incubation period is significantly shorter for the $\mathrm{Pb} / \mathrm{Zn}$ containing deposits, than the alkali sulphate deposits, though there are still significant differences in damage with varying $\mathrm{Na} / \mathrm{K}$ ratios in these 'deposits' after $2000 \mathrm{~h}$ testing. Similar deposit composition effects were observed at other deposition fluxes ${ }^{27}$.

The effect of deposition flux on the maximum corrosion damage obtained for IN738LC at $700{ }^{\circ} \mathrm{C}$ with a deposit mix of 80/20 mole\% $(\mathrm{Na} / \mathrm{K})_{2} \mathrm{SO}_{4}$ is illustrated in Fig. 6. This is typical of the response of gas turbine materials, with the dependence of corrosion rate on deposition flux being approximately sigmoidal with three distinct behaviour regimes $^{30}$ :

- at low deposition fluxes $\left(<\sim 1 \mu \mathrm{g} / \mathrm{cm}^{2} / \mathrm{h}\right)$ there were low corrosion rates;

- at intermediate deposition fluxes (from $\sim 1$ to $\sim 30 \mu \mathrm{g} / \mathrm{cm}^{2} / \mathrm{h}$ ), much higher corrosion rates were found with a dependence on deposition flux close to linear;

- at high deposition fluxes ( $>\sim 30 \mu \mathrm{g} / \mathrm{cm}^{2} / \mathrm{h}$ ), a thick scale/deposit layer was found which stabilises or even slightly reduces the corrosion rate with further increases in flux.

The effect of varying $\mathrm{SO}_{\mathrm{x}}$ and $\mathrm{HCl}$ concentrations on the hot corrosion damage of IN738LC at 650 and $700{ }^{\circ} \mathrm{C}$ were evaluated from a series of tests in which each of these

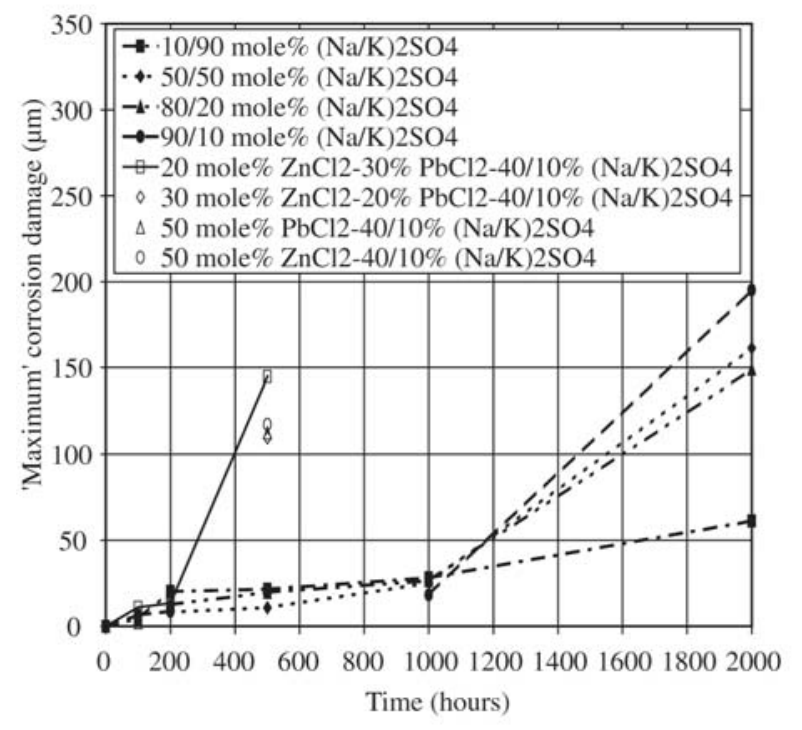

Figure 5. Effect of different deposit compositions on 'maximum' corrosion damage to IN738LC at $700{ }^{\circ} \mathrm{C}$ (deposition flux $\left.=5 \mu \mathrm{g} / \mathrm{cm}^{2} / \mathrm{h}, \mathrm{SO}_{\mathrm{x}}=2000 \mathrm{vpm}, \mathrm{HCl}=350 \mathrm{vpm}\right)^{29}$ 


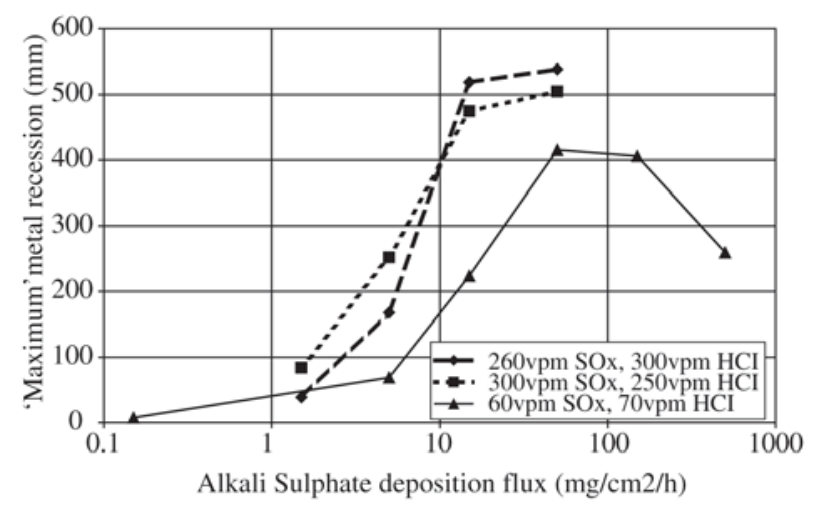

Figure 6. Effect of alkali sulphate flux and gaseous reactants on 'maximum' metal damage recession of IN738LC at $700{ }^{\circ} \mathrm{C}^{29}$.

contaminants was varied for the same 'deposit' composition $\left(80 / 20\right.$ mole $\left.\%(\mathrm{Na} / \mathrm{K})_{2} \mathrm{SO}_{4}\right)$ and a series of 'deposition fluxes'. It was found that the effect of $\mathrm{SO}_{\mathrm{X}}$ levels was much more significant than $\mathrm{HCl}^{27,30}$.

From the above, it is clear that great care is required in the control of trace alkali and other contaminants because of their potential to cause excessive corrosion damage to the hot gas path components of a gas turbine or gas engine using a biomass-derived fuel gas. The exact level of damage that can be tolerated depends on specific process and operating parameters (e.g. temperatures, materials, repair/ replacement strategy etc.), as well as economic factors. It may be possible to optimise the materials selection and operating conditions of a gas turbine, in combination with a comprehensive maintenance strategy (to allow it to handle higher than currently specified contaminant levels) instead of bearing the high cost of an elaborate gas cleaning system.

\section{Conclusions for biomass combined cycle systems}

From the above, it is clear that care is needed in designing the process flowsheets for biomass systems. In particular, those for fuels such as wheat straw, with very high $\mathrm{K}$ and $\mathrm{Cl}$ levels, require careful consideration of the removal of fuel contaminants so that a reliable and cost effective gas cleaning approach can be adopted.

For the lower efficiency atmospheric pressure systems, scrubbing to remove some of the residual tar and ammonia should also reduce significantly the water soluble trace contaminants such as $\mathrm{KCl}$. But as the gas is cooled substantially prior to scrubbing to minimise energy losses and to meet scrubber entry requirements, many of the trace contaminants may well have condensed onto entrained particulates or component surfaces, before the gas reaches the scrubber. To minimise costs, these systems do not have filters prior to the scrubber as for most large coal-fired IGCC plants, so the dissolved contaminants and the particulates will end up in the scrubber discharge. From the gas turbine perspective, the scrubbed fuel gas should not present any problems as nearly all fuel-borne contaminants should have been removed.

For the higher efficiency, pressurised systems appropriate hot, dry gas cleaning schemes are required to avoid the higher costs of scrubbing the high pressure fuel gas. Filtration is the key element, allowing the combination of particulate removal with condensed trace contaminants dependent on the filtration temperature. Filtration also allows for the use of in-duct injection of sorbents to reduce alkalis and $\mathrm{HCl}$ with minimal extra complication. However, because of the need to retain any uncracked residual tars in the vapour phase and the need to avoid condensation of ammonium compounds (both of which would lead to blinding of the filter elements), filtration temperatures cannot be reduced excessively in the drive to limit trace species. In these schemes, costly additional catalytic $\mathrm{NO}_{\mathrm{x}}$ reduction measures either upstream or downstream of the gas turbine may be needed. The gas turbine in these systems will be passing reduced levels of fuel-borne contaminants which pass the gas cleaning stages. There is scope to adjust the operation and materials of the turbine to suit the biomass fuel used; while, use of the highest efficiency turbine is an attractive option, it may prove uneconomic when the required gas cleaning costs are considered.

\section{References}

1. Energy for the Future: Renewable Sources of Energy Campaign for Take-off - a Community Strategy and Action Plan, EU Commission Paper, 1998.

1. Bridgwater, A.V. Biomass Gasification for Power Generation', Fuel, v. 74, n. 5, p. 631-653, 1995.

2. Rensfelt, E. Gasification Technology for Biomass and Other Solid Fuels, Biosolids Energy Recovery Technology Seminar, IWEX 2001, Birmingham UK, 2001.

3. Stahl, K.; Neergaard, M. IGCC Power Plant for Biomass Utilisation, Varnamo, Sweden, Biomass and Bioenergy, v. 15, n. 3, 1998.

4. 'Gas turbines in advanced co-fired energy systems', ECSC Project 7220-PR/053

5. Takematsu, T.; Maude, C.W. Coal Gasification for IGCC Power Generation, IEACR/37, IEA Coal Research, London, UK (1991). 
6. Reed, G.P. Control of Trace Elements in Gasification, Ph.D. Thesis, Imperial College, London (2000).

7. Frandsen, F.; Dam-Johansen, K.; Rasmassen, P. Trace Elements from Combustion and Gasification of Coal - an Equilibrium Approach, Prog. Energy Combustion Sci., v. 20, p. 115-138, 1994.

8. Fantom, I.R. An Assessment of Trace Element Concentrations in the British Coal Topping Cycle, Power Generation Report, n. 121, CRE, British Coal, 1991.

9. Clarke, L.B.; Sloss, L.L. Trace elements - emissions from coal combustion and gasification, IEACR/49, IEA Coal Research, London, 1992.

10. Kilgallon, P.J.; Simms, N.J.; Oakey, J.E. Fate of Trace Contaminants from Biomass Fuels in Gasification Systems, to be published in Materials for Power Engineering, Liege, 2002.

11. $4^{\text {th }}$ International Conference on Gas Cleaning at High Temperatures, Karlsruhe, Germany (Sept. 1999).

12. Nieminen, M. et al., Raskasmetallien käyttäytyminen turpeen ja kivihiilen leijukerros- kaasutuksessa, LIEKKICombustion Research Program. Project Report, 1991.

13. Kurkela, E. et al. Pressurized fluidized-bed gasification experiments with biomass, peat and coal at VTT in 19911994. Part 3. Gasification of Danish wheat straw and coal, VTT Publication, v. 291, 1996.

14. Kurkela, E. et al. Pressurized fluidized-bed gasification experiments with wood, peat and coal at VTT in 19911992. Part 1. Test facilities and gasification experiments with sawdust, VTT Publication, v. 161, 1993.

15. E. Kurkela et al., 'Pressurized fluidized-bed gasification experiments with wood, peat and coal at VTT in 1991-1994. Part 2. Experiences from peat and coal gasification and hot gas filtration'. VTT Publication 249, (1995).

16. 'Integrated hot fuel gas cleaning for advanced gasification combined cycle processes'. LIEKKI- Combustion and Gasification Research Programme. LIEKKIvuosikirjat, projekti: 410 (1996).
17. Proc. Corrosion in Advanced Power Plants, Special Issue of Materials at High Temperatures, vol. 14 (1997).

18. Proc. First International Workshop on Materials for Coal Gasification Power Plant, Special Issue of Materials at High Temperature, vol. 11 (1993).

19. Mitchell, S.C. Hot gas clean-up of sulphur, nitrogen, minor and trace elements, IEA Coal Research, UK, 1998.

20. Sims, C.T.; Stoloff, N.S.; Hagel, W.C. Superalloys II, Wiley (1987).

21. 'Hot Corrosion Standards, Test Procedures and Performance', High Temperature Technology vol. 7 (4) (1989).

22. 'Co-gasification of Coal/Biomass and Coal/Waste Mixtures', Final Report EC APAS Contract COAL-CT920001, University of Stuttgart, Germany (1995).

23. ASTM D2880, Standard Specification for Gas Turbine Fuel Oils (1990).

24. Decorso, M.; Anson, D.; Newby, R.; Wenglarz, R.; Wright, I.G. Int. Gas Turbine and Aeroengine Congress, Birmingham, UK, ASME Paper 96-GT-76, 1996.

25. Wright, I.G.; Leyens, C.; Pint, B.A. in Proc. ASME TURBOEXPO 2000, Munich, Germany, ASME Paper 2000-GT-0019, 2000.

26. Simms, N.J.; Encinas-Oropesa, A.; Kilgallon, P.J.; Oakey, J.E. Performance of Gas Turbine Materials in 'Dirty Fuel' Environments, to be published in Materials for Power Engineering, Liege, (Oct.2002).

27. Leyens, C.; Wright, I.G.; Pint, B.A. Hot Corrosion of Nickel-based Alloys by Alkali-containing Sulfate Deposits, $5^{\text {th }}$ International Symposium on High Temperature Corrosion and Protection of Materials, Les Embiez, France (May 2000).

28. Simms, N.J.; Smith, P.J.; Encinas-Oropesa, A.; Ryder, S.; Nicholls, J.R.; Oakey, J.E. in Lifetime Modelling of High Temperature Corrosion Processes, Eds M. Schütze et al, EFC No. 34 (Maney Publishing, London), p. 246-260, 2001.

29. Simms, N.J.; Nicholls, J.R.; Oakey, J.E. in Materials Science Forum, v. 369-372, p. 833-840, 2001. 
